\title{
Absence of a Universal Treaty on Foreign Investment and Movement toward It
}

\author{
Leila Raeisi $^{1} \&$ Abdolnaeim Shahriari ${ }^{1}$ \\ ${ }^{1}$ Department of Law, Isfahan (Khorasgan) Branch, Islamic Azad University, Isfahan, Iran \\ Correspondence: Abdolnaeim Shahriari, Department of Law, Isfahan (Khorasgan) Branch, Islamic Azad \\ University, Isfahan, Iran. E-mail: shahriari137@gmail.com
}

Received: June 6, 2016 Accepted: June 27, 2016 Online Published: June 29, 2016

doi:10.5539/jpl.v9n5p299 URL: http://dx.doi.org/10.5539/jpl.v9n5p299

\begin{abstract}
Foreign investment is today one of the most important pillars of economic and social development. Having passed several ups and downs, the legal regime governing foreign investment could be now called the result of a vast range of developments. An in-depth study of these developments will provide a comprehensive outlook for preparing a roadmap of the law on foreign investment both from a national and transnational perspective. In this regard, one main question would be whether the development of rules in the field of foreign investment has prepared the required conditions and basis for conclusion of a universal treaty on foreign investment? Plus it is to be clarified as to what would be the appropriate approach for regulation of foreign investment from the international aspect. While studying the developments in the recent decades, the present paper will review the perspectives for conclusion of a universal foreign investment treaty and the process for such a treaty.
\end{abstract}

Keywords: foreign investment, universal treaty, international customary law, bilateral treaties

\section{Introduction}

Foreign investment refers to a process through which the foreign investor intends to enter the reliable markets via transfer of capital to the host state. In this process, the investor and the host state are faced with two big concerns, on the one hand the investor is concerned with the risk of the safe return of the capital to the mother/national state; and on the other hand, the host state is faced with a concern regarding the presence of foreign investor in its territory and the possibility of interference in the economic and political situation.

A review of the developments undergone by the rules and regulations governing the foreign investment indicates that the current rules are on the one hand a result of the different views and opinions in this filed and on the other hand, a result of different political and economic factors in different periods of time. As a matter of fact, the almost sustainable fluctuation existing in the field of foreign investment has yield to formation of different layers of rules including national rules, bilateral rules and regional rules.

Accordingly it would be of importance to see the reason beyond this huge pool of rules and whether, considering the current situation of the international scene, it is possible to move toward a universal treaty on foreign investment. In this regard, few questions need to be answered; what are the factors involved in formation of the legal framework governing the foreign investment? Whether the process of developments in the rules of foreign investment in line with the needs and conditions of each period of time, in other words, whether these rules contain the required dynamism and flexibility as to regulate the process of foreign investment? Can the approach seen in the globalization era move toward a universal treaty on foreign investment?

Analysis of the current rules on foreign investment and the movement toward a universal treaty on foreign investment requires a careful examination of the process of formation of the law on foreign investment through bilateral and multilateral treaties. Until the $90 \mathrm{~s}$, not a significant development can be seen in the rules of foreign investment. However, after the collapse of the former Soviet Union and an increase in the relationship between the states, the flow foreign investment also experienced new developments and changes; such developments required a new legal framework.

This trend led to efforts for codification of universal rules on foreign investment and finally a comprehensive universal treaty in this regard. 


\section{Colonialism Era}

Regulation of economic relations at the international lever requires special arrangements in different periods of time. In colonial times, protection of trade relations through the legal mechanisms was not a big concern for the colonialist states. At that time, particularly in the $18^{\text {th }}$ and $19^{\text {th }}$ century, a significant part of the investments by powerful states was made in the territory of the colony and since the judicial and legislative powers of these states was mostly under the control of the colonialist state, international regulation for protection of such investments was not a significant concern. (Frieden, 1994, pp. 559-593)

\subsection{Economic Relations between the Colonialist State and the Colony}

Considering the military and economic powers of the colonialist states in the colonial times, the regulation of specific rules though conclusion of bilateral or multilateral treaties for protection of trade and investment in the territory of the colony was not a significant concern. By entering into relations with the local high rank authorities, the colonialist state would penetrate the supervisory and executive bodies of the colony and would consequently led the economic rules and regulations compatible with their desired outcomes and objectives. Therefore, establishment of an international legal framework specifically for protection of economic relations with the colony was not a necessity. (Hadadi, 1379, p. 240). In other words, the nature of relations between the colonialist state and the colony was so that basically there was no need for definition and adoption of universal rules regarding foreign investment; simply, the power relation would itself guarantee the durability and protection of economic relations between the two.

\subsubsection{Regulation of Economic Relations through Non-Legal Mechanisms}

Powerful states have usually approached the risks entailed in expropriation of the investments of their nationals through political and/or military ways. Use of such means especially resort to military intervention seemed justified considering the conditions governing the relations between the colonialist and colonies at that time. In practice, a combination of diplomacy and military threats was used to prevent any measure of host state in expropriation of the property and investments of foreign nationals. (Brownlie, 2008, p. 500)

\subsubsection{Regulation of Economic Relations through Legal Means}

The old military means could not address the new developments. Accordingly, states moved toward legal framework to deal with such issues. The nature and type of relations between the states in the colonial times was did not welcome the use of legal means for regulation of such economic relations. As a matter of fact, the power relation governing the relationship between the colonialist and the colonial states on the one hand, and the simplicity and width of the economic relations on the other hand, could not accept the establishment of legal frameworks and the powerful states preferred diplomacy and occasionally, the military means. However, gradually, these means proved to be unsuccessful and the need for a more acceptable and legitimate scheme was felt. Consequently, legal means found a way to regulating the economic relations.

\subsubsection{International Customary Law}

Lack of trust in efficacy of political and military means for protection and continuation of the investment relations led the investing states toward customary legal mechanisms for protection of their nationals. Some authors believe that the only legal source for protection of foreign investment in the colonial times were customary rules of international law; in this vein, they refer specifically to a criteria called 'minimum standard of treatment of foreign investors'. According to this standard, states are obliged to apply a minimum of rights and principles in their treatment of foreign investors irrespective of their internal laws and regulations. (Brownlie, 2007, p. 691 \& Gazzini, 2007, pp. 562-64).

In this respect, the international legal order has made several efforts to adopt some universal regulations governing the foreign investment. However, despite all efforts of the investing states to codify and consolidate an international standard for treatment of foreign investors, this mechanism has failed to prove successful in ensuring the security of foreign investment.

\subsubsection{Bilateral Legal Mechanism}

Use of contractual mechanism was another approach followed in the colonial era in order to regulate the economic relations. The history of using international trade agreements dates back to the $18^{\text {th }}$ century. In addition to invocation of customary international rules, the colonialist states would conclude bilateral treaties with their trade partners in order to strengthen their economic relations as well as to protect their nationals' property. These bilateral treaties are of special importance particularly from the viewpoint of provisions entailed in them. As a matter of fact, one of the main reasons for conclusion of such treaties in those times was to respond to the 
insufficiency and lack of transparency of customary rules for protection of foreign nationals and their property in the territory of host state. (Newcombe, 2009, p. 41)

\section{Decolonization Era or Regulatory Era}

In this era, the legal system governing foreign investments were dramatically changed. Shaping the legal system governing foreign investment, one of the environmental factors was the international community's response to the severe downturn in the international arena, as considered as one of the fundamental factors flare World War II. In this regard, taking into account the economic situation before the war, the victorious nations of World War II adopted a policy of trade liberalization with the approach to establish of multilateral legal framework; which was presented to the world, in 1947, as the "General Agreement on Tariffs and Trade" (GATT) market. (Bagwell \& Robert, 2002, pp. 43-48) GATT establishment is a milestone and great development in the field of regulation of foreign trade because for the first time the legal system governing the foreign trade jumped from the limited framework of bilateral agreements into the multilateral system.

Another factor involved in the process of establishment of the postwar legal system was decolonization movement and the birth of newly independent countries with fragile economies affected by the new economical approaches and to preserve the independence and territorial integrity. These countries attempts to close the doors to new investors and nationalize previous investment. (Salacuse, 2005, p. 75)Such a movement was faced the countries of origin of foreign investment with an unprecedented crisis; while legal instruments to support investment were not enough developed. This led the international system to an interest to adopt universal regulation on investment.

\subsection{Bilateral Treaties and Moving Forward}

The International Court of Justice in the Barcelona Traction case, in the early 1970s, stated there is much surprise that despite the growing of foreign investment and expanding cross-border activities of companies, the foreign investment law in international arena did not change in the past half century and no generally accepted principles in this area has not crystallized. This legal vacuum and need to develop the rules governing foreign investment, especially to avoid confiscation of property, led to suggest bilateral treaties framework as the most effective way to harness the absolute authority of the host governments. So, we can see the expansion of bilateral investment treaties on foreign investment (UNCTAD, 2005, p. 8).

\subsection{Multilateral Treaties}

Although developments of foreign investment law in the mutual legal bases subside the concern and bustle of the investors in connection to guarantee of security of investment but the challenge in regulating of foreign investment in the multilateral era of decolonization continued to the era of globalization. History of the international community's efforts to develop a law on foreign investment in a multilateral dimension went back to the years before World War II But since then has continued and could have an impact on concluding a universal treaty on foreign investment.

\section{Globalization and Move to a Universal Treaty}

The evolution and development of the rules governing foreign investment entered a new phase, since the early 1990s with the collapse of the Soviet Union, called "the era of globalization or the move to Universal treaty to foreign investment". In the light of the development of economic relations and the fade of national law, foreign investment law developed in the light of the provisions of international (bilateral and regional treaties). In this period, the primary purpose of a bilateral or regional treaties was changed; i.e. Although, In the previous period (the era of decolonization) The basic aim of signing international agreements, particularly bilateral treaties guarantee and protect foreign investments in the territory of the host governments; In the era of globalization the basis of adoption of mentioned agreements were set to facilitate the flow of capital from a macro perspective, the change of general view to liberalizing of capital flows was caused by important events that made significant changes in perimeter of foreign investment and regulations governing it. Excessive coagulation of treaties, particularly bilateral treaties during this period overshadowed the foreign investment law in a way that the mentioned time can be called as the era of moving toward Universal treaty of foreign investment.

\subsection{Universality of Bilateral Treaties}

The formation of approach to bilateral treaties to control the unilateral actions of host countries in the era of decolonization were recognized as a key development in the law on foreign investment that calm the challenges between the opposing forces. Yet, before the 1990s, the remarkable thing is that the use of these treaties to regulate investment relations is limited to a certain number of countries. Between 1959 and 1989, only 386 bilateral treaties signed between countries; such statistics reveled a quite negative attitude and the reluctance of 
developing countries to attract foreign investment (Schill, 2009, p. 41).

However, in the era of globalization, another development that influenced the environment of foreign investment was the unprecedented expansion of bilateral treaties of foreign investment, which represents a significant change in attitude of developing countries on foreign investment is attracted. It is worth noting that by the end of 2010, the 2807 bilateral treaties which is geographically cover almost all of Earth were concluded between the countries (UNCTAD, 2011, p. 100).

Although the development of bilateral foreign investment law clearly shows the tendency of countries in the regulation of relations between host governments and international investors by transnational law but challenging issue is that despite of these developments, foreign investment is still imbued with the challenges that could not be response by bilateral treaties. (Sornarajah, 2010, pp. 224 - 231) The universality of bilateral treaties in practice has led each country to sign parallel treaties with other countries that do not have significant difference in terms of content And provide a context for the question whether the repeated and continuing procedure through the bilateral treaties countries has been formed a kind of customary international law in the field of foreign investment? There are two different views In connection with the emergence and evolution of customary law of foreign investment through the bilateral treaties:

Some believe that the structure and provisions of bilateral treaties and their close similarity to substantially implies creation of stable and binding procedures between countries on how to make and how to deal with foreign investors. (Kelly, 2000, pp. 501-503)

Others believe, however, in terms of appearance and structure of bilateral investment treaties are somewhat similar to each other but deeper look shows content of such treaties, despite the similarity in appearance significantly differ. Each of the treaties is concluded after several rounds of negotiations and taking into account the interests and specific circumstances of the parties. Since the economic interests and conditions of countries are different it is obvious that treaties will not be contained the same and united provisions; Therefore the best description for these bilateral documents is that each of them creates its own rules between the parties And mere similarity of appearance cannot be decisive reason to extract the customary rules from the root of the documents (Kishoiyian, 1994, pp. 327 - 329 \& Salacuse, 2005, pp. 655-660).

Scrutinize and deliberate on a range of bilateral treaties show that there is not essential unity between provisions to crystallize the customary law (Arian, 2009, pp. 123-137). The necessity to conclude and proliferation of these treaties is nothing more than the lack of efficient system of international law, especially customary international law to protect foreign investment. In other words, the main purpose of signing these treaties is the establishment of transnational legal system distinct from customary international law has been applied for maximum protection of foreign investors. Some efforts to prove the birth of bilateral investment treaties from the womb of customary law stems from the practical fact that Because of defects of such treaties on the one hand, and the lack of universal treaty in the field of foreign investment on the other hand, the need for universal rules in the area of foreign investment is more crucial than ever. Hence it seems that recourse to customary law which is originated from treaties is suitable for filling the gaps in the system of law governing foreign investment.

\subsection{The Absence of a Universal Treaty: Stop at the Last Station?}

In the era of globalization, the main challenges in the field of foreign investment are the transition from the dominant system of bilateral and regional treaties to reach the final goal that is the conclusion of a universal treaty for optimized and institutionalized foreign investment law. The challenge whose resolution is now in doubt and the has created an images in the international economic interactions that the boat of foreign investment aground in last station and effort to get out of this crisis will have nothing but the destruction of the boat. The pre-requisite to better understanding of the challenges of globalization of foreign investment law is, in the first place, the analysis of what approaches and measures have been taken in this regard since the beginning of the 1990s. On the other hand, due to the failure of the international community in achieving the ultimate goal and deepening the concerns in human rights violations and environmental regulations in the process of foreign investment, the future of Regulating of foreign investment would be in question.

\subsubsection{Universalizing the Foreign Investments Law: Approaches and Actions}

In the 1990s, one of the noteworthy efforts to globalize the foreign investment law was carried out by the Organization for Economic Cooperation and Development. By the initiative of the United States, in 1991, adoption of a multilateral agreement on foreign investment were put on the agenda of the organization. The relevant negotiations behind closed doors started in 1995 and lasted almost three years. In 1998, upon public declaration of draft of agreement, strong opposition of developing countries and international non-governmental 
organizations forced negotiators to stop. (Muchlinski, 2000, pp. 1033-1054) Although Careful and expertly examination of causes of failure are outside the scope of this article. (Arian, 2009, p. 472) But from a macro perspective, this fact must be mentioned that the adopting a non-cooperative approach to negotiations carried out internally and behind closed doors, by industrialized countries of Organization of Economic Cooperation and Development (OECD), led non-member countries, especially the developing countries to follow the aim and purpose of negotiators with suspicion and doubt. Finally, described approach cause to detriment of the members of the organization since the publication of the draft was evident the fact that the document in question is nothing more than a corporate investor Bill of Rights. Not only the agreement was not taking into account the interests of other countries but also was not pay any attention to human rights and environmental challenges arising from foreign investment (Morehouse, 1998, pp. 12-16).

Other notable action in regulation of foreign investment in the multilateral era was empowered by establishing "working group on relationship between trade and investment" by the WTO in 1996. One of the issues on the agenda of this working group was to discuss and exchange ideas about the necessity of setting A multilateral agreement on foreign investment in the framework of the World Trade Organization (WTO). Despite the negotiations of OECD, the obvious character of working group was adopting a participatory approach in discussions by active participation of Developing countries. In its annual report to the General Council of the WTO (2000) Working Group was emphasized on the existence of the gap and sharp disagreement between developed and developing countries in the field of multilateral regulation in investment issues. After many ups and downs in process of debate on regulation of foreign investment law empowerment rights issue of in various rounds of WTO Including the conference of Doha, Qatar (2001) and the Conference of Mexico city, Mexico (2003) the WTO General Council by July 2004 agreement was decided to exclude the subject of conclusion a multilateral agreement on investment from the agenda of negotiations of the WTO. However, unlike the OECD, the approach taken in the framework of the WTO was based on active participation of developing countries in the negotiation process but in practice, because of the widening gap between the views and interests of member states of the WTO, no significant changes in the universalization of foreign investment law were occurred.

\subsubsection{The Foreign Investment Law in the Tomorrow Mirror}

Since the early 1990s, the process of globalizing the foreign investment law has experienced two great examinations, which contrary to the early expectations, their results were not satisfactory. What the world achieved through the first examination was that the universal evolution of foreign investment law requires a cooperative approach to be developed for reaching to a balanced point which the opponent ideas and interests of beneficiaries can be considered equally. Without such approach, it seems the establishment of any global rules in regard of standard behavior to foreign investment will lead to failure.

In the second examination, although the approach was established on the basis of interaction and cooperation, but due to different ideas and conflict of interests of concerned states and groups and failure to prepare proper ground triggered that the negotiation was not led to considerable achievements. According to these experiences, what the foreign investment law in form of globalization requires is to deeply think and step on the two below-mentioned ways:

A: conflicts recognition and ground preparation: The legal evolutions in the foreign investment relations do not take place autonomously, which they can be occurred under time and place occasion. But, they need the beneficiary states and groups move forward. Nowadays, given the complexity and expansion of international economic relations, the truth is that the development of steady rules to reduce such complexity and increase the efficiency is necessary.

The relative appropriateness is hidden in this fact that instead of increasing the investment risks by variety of national rules and bilateral international treaties, states should find a way that it finally leads to reduction of existing risks through establishment of steady rules governing the parties' relations. In fact, without recognizing the sickness, it is impossible to identify its treatment or medicine. This fact has the objective witness in field of making rules.

The fundamental purpose of developing rules is to remove the conflicts in human community. If the recognition of such conflicts is not done properly, not only the rules cannot help to obviate the discrepancies, but also these challenges can be intensified by abusing the rules. The existence of conflict of interests among states' economic relations is normal fact. So, what is critically important is to identify the challenging centers truly and regulate purposefully in order to obviate such centers. Tension-making and conflictions are both one of essential dimension of foreign investment. This, itself, makes the constructive regulating in this field problematic, particularly when the regulation is considered at the world scale. Anyway, the first step for globalizing the 
foreign investment law is recognizing and deeply analyzing sensitive-making points in states' investment relations, which the process for realization of such goal absolutely will take much time. After identifying challenging centers, the vital key for solving the puzzle of globalizing foreign investment is to provide required grounds to remove such conflicting centers among states' relations.

A question coming to the mind in regard of ground preparation is that required measures for developing world-scale foreign investment law must be based on what pillars? Should the sole economic considerations be regarded for development? Or further, development with social-economic orientation should be foundation?

B: the evolution of foreign investment law on the basis of sustainable development: practically, until each states behave separately and island-like and move only to provide their own economic interests, due to far conflictions among interests, the agreement on globalizing law for investment seems almost impossible. So, gathering of opposing interests depends on the change of existing approach (sole support of foreign investment) toward an approach in which the interests of human community are considered. In other words, a approach making evolution based on sustainable development can provide constructive interaction among states' interests. (Shahbazi, 2000 pp.127-129 \& Shamsaiee, 2007, pp.10-12).

Although the concept of the sustainable development comes from the international environment law but it is going to complete a new concept which derives from relation of three concepts of economic development, environment support and human rights. The foreign investment as a main pillar of economic development is always accompanied with adverse environmental consequences. This is while the national regulations, bilateral and regional treaties support foreign investment without environmental considerations and just with adoption of economic approaches. Thus, it is clear that the globalizing law of foreign investment will leads to fail without control of its adverse consequences .In other words, the dynamic evolution of foreign investment law in world-scale needs to accept a universal insight, step on outside of borders and move toward the law of sustainable development.

\section{Looking Forward: Suggestions}

As a matter of fact, it is well obvious that the most effective mechanism for regulating foreign investment in the era globalization is to lay down a comprehensive global framework. However, the real problem in the context of foreign investment regulation seems to be a method of mustering divers view. In the light of experiences acquired from previous failure of universal regulation of foreign investment, in can be said that the success of any future initiative would hinge upon observance of several important points that can be summarized as follows:

A) Having a balance approach: find a fair and acceptable balance between the conflicting interest and expectations of all the players in the context of foreign investment must form cornerstone of any possible agreement on investment. Each of players has distinctive interests to further. Multilateral Enterprises (MNEs) and Non Governmental Organization (NGOs) representing business, will seek a business friendly environment that offers as few unnecessary regulatory hurdles as possible to the free choice of operating means. Public interest NGOs will seek to control what they perceive as excesses of corporate power and strive for greater accountability of firms in relation to the public interest goals the NGOs support. Host countries will seek to attract and benefit from the investment that MENs offer, while home countries will encourage outward investment that brings useful economics and political returns to those countries. Additionally, the major problem of existing bilateral and regional arrangement on investment is that they are too much one-side, that is to say, the only concern within them is to protect the interest of foreign investors and their home states without showing any enthusiasm to accommodate the interests of other player most notably host states. Having focused on this point, the Doha Declaration mandates that the investment solutions should reflect a balanced manner the interests of home and host countries and take due account of the development policies and objectives of host government as well as their right to regulate in public interest. Finding that elusive balance is what the game is about. The obvious starting point is to ditch those views and interests that form the main centers of conflicts; then next major step must be towards exploring the answer of this question how can those conflicts be balanced in a way acceptable to all foregoing players? This is a truly difficult task to implement which requires policy makers to engage in several rounds of negotiations. Additionally, it calls for a widespread cooperation and between international active players in the context of foreign investment.

B) Having flexibility (right to regulate): with respect to subject-matter of the possible global rules on foreign investment, an important lesson learnt from recent international investment negotiations and from the debate in World Trade Organization (WTO) is that a global framework of rules on investment cannot simply conceived as a consolidation of provisions typically contain in regional and bilateral investment agreements. The experience 
with the Multilateral Agreement on Investment (MAI) in framework of OECD suggests that the legitimacy of traditional investment protection rules has engendered controversy with regard to their implication for the ability of governments to regulate economic activities in their territories. Indeed, the right to regulate foreign investment from the entry to final liquidation lies at the root of conflicts concerning the making of a global instrument on investment.

Nevertheless, the point is that marrying the underlying philosophy of liberalization in global instrument with the preservation of the right of regulation is not an easy task; as the case of global agreement on investment showed, even developed countries faced such a problem between themselves in drafting an instrument on investment. When it comes to the inclusion of the developing countries and the tasking into account of the development dimension, as the Doha Declaration directs, the problems become compounded. For developing countries, the right of regulation lies at the root of foreign investment policy. Most of the domestic laws on foreign investment are premised on this fact. Therefore, no global agreement on investment can come about unless this fundamental inconsistency is resolved. The issue of the rights to regulation will remain a stumbling block that cannot be avoided. The Doha Declaration provided that the investment solutions should reflect in a balanced manner the interests of home and host countries, and take due account of the development policies interest. Moreover, the North American Free Trade Agreement (NAFTA) litigation has certainly caused some concern as to whether investment protection has gone too far. The litigation strategies evidence a disregard of the state's right to regulation which discomforts the United States and Canada to such an extent that interpretative devices have been used to ensure that the regulatory right of the state are not diminished. In that context, it is unlikely that there would be a keenness to draft a global agreement on investment which does not recognize the right to regulate.

C) Having transparency: universal agreement on investment failed due to lack of transparency, that is to say, all the negotiation conducted behind closed doors. This secrecy made both developing countries and NGOs suspicious in a way that finally they campaigned against the negotiation. It is crucial to mention that confidentiality is a determining element in complex international negotiations, but it should be used wisely. Secrecy, or even a just the impression of secrecy, is a time bomb in today's information society. On the other hand, openness can provide important guidance for negotiations. The additional inputs from different groups in society shed more light on priorities to be given to the subjects under negotiations and on the scope of contentious issues. Using the additional analytical capacity can lead to a better understanding of the problems in hand and to finding improved solutions. Accepting to be challenged on both principles and content of an agreement and actively participating in the ensuring debates will lead to better end results.

Form the foregoing, it seems well obvious that, of necessity for any future negotiations on investment is transparency; an element which can provide a more friendly environment for negotiations. It is worth noting that the internet plays a crucial role in providing transparency. This is due to the fact that the NGOs campaign against multilateral negotiations on investment in 1998 was so effective because of their intensive use of internet.

D) Having an integrated approach: implementing a balanced approach also requires an integrated approach in the sense that any future initiative must be more representative in terms of the participating countries. The active involvement of developing countries and counties in transition is essential. Apart from this, it is so determining to use expertise from different quarters. Both at the national and finance, development, environment, labour standards, human rights and other relevant field should be consulted. Not only government experts but also academics and NGOs can provide valuable input.

E) Having suitable institution: it has been argued that WTO is the most appropriate forum to fashion investment disciplines. This idea is supported by a number of grounds. As a first ground, it is claimed that there is deep interactions between trade and investment matters which pave the way for producing investment norms in the framework of WTO. It is also claimed that although WTO Agreement does not include a separate legal instrument on foreign investment. Some of the Agreement attached to the WTO Agreement pertains directly or indirectly to foreign investment. (Brewer \& Young, 1998, pp. 457-470).

F) Having enthusiasm for sustainable development: a global agreement on investment is not the real problem; it is just a good focal point for concerns about globalization in general. With the strong upsurge of investment, the effects of globalization have become the center of attention in different locations. Where most governments are still positive about investment and are actively trying to attract it, NGOs have focused to discuss the possible negative of foreign investment as one of the driving forces of globalization. The point is that adverse impacts of foreign investment on human rights, environment and labour rights have cast doubts about how effective the existing bilateral and regional arrangements really are. In the light of these doubts and the widely recognized 
notion of sustainable development, it seems apparent that only new normative framework can assist policy makers to deal with the unwilling consequences of foreign investment.

G) Having progressive liberalization: the failure of the global agreement on foreign investment showed that even the developed countries cannot agree on a fast-track liberalization agreement. The major lesson is that negotiation of a global agreement on investment is not a zero-sum game, with either full liberalization or full protectionism as the possible outcomes. Perhaps inevitable result will be an agreement with some liberalization and some protectionism. One way around this could be to abandon the global agreement on investment to liberalization coupled with "top-down" lists of exceptions, and to adopt the more cautious approach of selective liberalization whereby a country opts-in to liberalization by specifying the sectors in which it is willing to accept such disciplines while leaving non-specified sectors outside the agreement.

The "top-down approach" is an approach that sets general high standards for almost all economic sectors in one agreement with some specific expectations as an annex to the agreement. In the case of global agreement on investment, the negotiating parties made an overall commitment to absolute standards, and then listed country-specific exceptions for those areas they did not wanted to be covered by the agreement. The approach in contrast with the top-down approach is the "bottom-up" approach which starts with an initial agreement that contains a few general lower commitments, and provides a benchmark towards which the contracting parties agree to proceed. Each partied makes an offer and negotiates the liberalization of obligations it will undertake in its schedules. After the agreement comes into effect, new regular negotiation rounds are conducted to discuss each party's new offers of further advances towards the elimination of restrictive measures.

\section{Conclusion}

The foreign investment is one of the major pillars of each states' economic foundation, which its efficiency depends on the mass economic policy-making from one hand, and developing proportionate rules to achieve the mentioned purposes from other hand. The obvious transnational feature of foreign investment causes both mass economic policies and national regulations to be affected by international economy and the rules governing states relations.

In the colonialism era, rules, or in more common concept, law, were playing small role in regulating investment relations among states. And, the support of foreign nationals' interests was often based on diplomacy and armed power. In this era, the winner and loser nature of economic relation between colonizing state and colonized state does not necessitate any needs for developing legal frameworks. And such kind of relation also guaranteed their security. Invocation to vague customary rules and conclusion of bilateral trade agreements were the only legal tools for regulating foreign investment in the colonialism era. So, speaking of the rule of law in states' relation seems disappointing.

In the decolonization age, opposition of national rules to bilateral treaties results in the unparallel development of foreign investment law. Because, the national rules are often made with view of rejecting foreign investment or regulating the guarantee of their exit and entrance, while the bilateral treaties try to emphasize extremely on making and guaranteeing the rights of investors. Despite different attempts to develop the investment law, bilaterally and regionally, multilateral development as a challenge remained to be considered for the next era.

Globalization age and collapse of the Union of Soviet Socialists Republics which reveals the failure of communistic economic thoughts and change of developing countries' approach to more attraction of foreign investment opened a new chapter of foreign investment book. The adoption of economy liberalization policy by many countries in this time triggers to increase the foreign investment volume. For more attraction of foreign investment, states changed their own national rules by withdrawing from the contractionary policies and offering incentives to and supporting investors. This accelerated the conclusion of bilateral agreements with the same expansive approach, in a way that in the globalization age, we witness the parallel development of foreign investment law both in national and transnational dimension.

The only achievement of two great examinations, which have been taken placed for globalizing the multilateral development of foreign investment in this era, was recognition of deep gap between ideas and interests of beneficiary states and groups in respect of method and manner of regulating foreign investment in universal scale.

Currently, the mere economic approach in bilateral treaties and regional documents for supporting the interests of foreign investors as more does not suffice to satisfy the existing needs and necessaries in field of foreign investment.

The control of adverse environmental consequences and observation human right along with necessary 
considerations of foreign investment require the adoption of a comprehensive and universal plan in which the regulation is made on the basis of sustainable development.

Nevertheless, something that we should always take it into account is the evolution of foreign investment law, naturally, does not occur autonomously, and under time and place occasion change, but, despite the environmental factors, it requires to understand the necessity of change of beneficiary countries and groups' approaches and step forward by identifying conflicting centers and removing them through appropriate ground preparation.

\section{References}

Arghyrious, F. (1995). Towards an International Agreement on Foreign Direct Investment. ICSID Review-Foreign Investment Law Journal, 10.

Arian, M. (2002). The Need for Fashioning Comprehensive Global Rules in the Context of Foreign Investment: Reality or Dream. Journal of Legal Research, 56.

Arian, M. (2009). Necessity a Comprehensive Worldwide Agreement on the legal Standards of Foreign Investment. A Dissertation Submitted to Obtain Master Degree, London: and Shahid Beheshti University.

Bagwell, K., \& Robert, W. S. (2002). The Economics of The World Trading System. Massachusetts Institute of Technology (MIT) Press.

Bernard, K. (1993). The Utility of Bilateral Investment Treaties in the Formulation of Customary International Law. Journal of World Investment, 6(3).

Brewer, T., \& Young, S. (1998). Investment Issues at the WTO: the Architecture of Rules and the Settlement of Disputes. Journal of International Economic Law, 1(3). http://dx.doi.org/10.1093/jiel/1.3.457

Brownlie, I. (2008). Principles of Public International Law. Oxford. Oxford University Press.

Brus, A. (2001). Multilateral Regulation investment. The Hague, Kluwer Law international.

Chen, H. (2002). OECD'S Multilateral Agreement on Investment: A Chinese Perspective. The Hague, Kluwer Law International.

Doak, R., \& Reisman, W. (1999). Foreign Investment Disputes. The Hague, Kluwer Law International.

Frieden, J. (1994). International Investment and Colonial Control: A New Interpretation. International Organization, 48(4). http://dx.doi.org/10.1017/S0020818300028319

Gazzini, T. (2007). The Role of Customary International Law in the Protection of Foreign Investment. Journal of World Investment \& Trade, 8(5). http://dx.doi.org/10.1163/221190007X00143

Jacques, W. (2003). Making Investment Arbitration More Certain - A Modest Proposal. Journal of World Investment, 4(5).

Kelly, J. (2000). The Twilight of Customary International Law. Virginia Journal of International Law, 40(2).

Kennedy, K. (2003). WTO Agreement on Investment: A Solution in Search of a Problem. University of Pennsylvania Journal of International Economic Law, 24(77). http://dx.doi.org/10.2139/ssrn.438761

Kenneth, J. (1998). Investment Liberalization and Economic Development: The Role of Bilateral Investment Treaties. Transnational, 30.

Kishoiyian, B. (1994). The Utility of Bilateral Investment Treaties in the Formulation of Customary International Law. Northwestern Journal of International Law and Business, 14(2).

McDonald, J. (1998). The Multilateral Agreement on Investment: Heyday or Mai-Day for Ecologically Sustainable Development. Melbourne University Law Review, 22(617).

Miller, S. (1959). Protection of Private Foreign Investment by Multilateral Convention. The American Journal of International Law, 53(2). http://dx.doi.org/10.2307/2195809

Morehouse, W. (1998). The Multilateral Agreement on Investment: An International Human Rights Crises. Guild Paractitioner Journal, 55.

Muchlinski, T. (2000). The Rise and Fall of the Multilateral Agreement on Investment: Where now. The International Lawyer, 34(3).

Newcombe, A., \& Paradell, L. (2009). Law and Practice of Investment Treaties: Standards of Treatment. The Hague, Kluwer Law International. 
Patrick, L. (1996). Beyond TRIMs: A Case for Multilateral Action. In W. Martin, \& L. Winters Alan (Eds.), The Uruguay Round and the Developing Countries. Cambridge: Cambridge University Press.

Salacuse, J. W. (2005). BIT by BIT: The Growth of Bilateral Investment Treaties and Their Impact on Foreign Investment in Developing Countries. International Lawyer, 28(3).

Schill, S. W. (2009). The Multilateralization of International Investment Law. Cambridge University Press. http://dx.doi.org/10.1017/cbo9780511605451

Schwartz, B. (2003). The Doha Round and Investment. Asper Review of International Business and Trade Law, $3(1)$.

Shahbazi, A. (2000). Sustainable Development in International Law. The Iranian of International Law, 42.

Shamsaiee, M. (2007). International Economic Law and the Principle of Sustainable Development. The Iranian Magazine of Law and Poetical Research, 19.

Sornarajah, M. (2010). The International Law on Investment. Cambridge University Press.

Steven J. C. (1998). The Multilateral Agreement on investment. Cornell international Law Journal, 31.

Sturchler, N. (2007). The Threat of Force in International Law. Cambridge University Press. http://dx.doi.org/10.1017/cbo9780511494338

UNCTAD. (2005). World Investment Report 2005 - Transnational Corporations and the Internationalization of $R \& D$ (Geneva: United Nations Conference on Trade and Development).

UNCTAD. (2011). World Investment Report 2011, United Nations, Geneva and New York.

\section{Copyrights}

Copyright for this article is retained by the author(s), with first publication rights granted to the journal.

This is an open-access article distributed under the terms and conditions of the Creative Commons Attribution license (http://creativecommons.org/licenses/by/3.0/). 